UDC 811.11-112

DOI: $10.17223 / 24109266 / 10 / 2$

\title{
NAMES OF ANCIENT HEROES TRANSFERRED ON THE TYPES OF WEAPONS AND PROTECTIVE EQUIPMENT (BASED ON ENGLISH AND GERMAN LANGUAGES)
}

\author{
I.L. Kuchesheva
}

\begin{abstract}
The article deals with lexical and etymological analyses of names of ancient heroes transferred on the types of weapons and protective equipment based on English and German languages. The relevance of this study is determined by the fact that the ancient myths denoting the names of weapons and protective equipment are not sufficiently studied both in domestic and in foreign linguistics. The article gives the definitions to such notions as myth, mythonymy, mythonym, onomastics, general cultural lexicon, weapons, and protective equipment. Methods of etymological and lexical-semantic analysis and the method of continuous sampling were used in the study. The paper considers the following names of weapons and protective equipment in English and German languages, taken from ancient mythology and gives their thematic classification: swords, cudgels, tridents, spears, bows, arrows and shields. Their etymology is given for appropriate usage of types of weapons and protective equipment with a name of ancient hero in the process of intercultural communication. The author pays attention to the peculiarities of their spelling. As a result of lexical and etymological analysis the author comes to the conclusion that the peculiarity of names of ancient weapons and protective equipment with a component-mythonym in English and German languages is that they refer to general cultural lexicon as they are used in two or more languages, have one source language and they are the heritage of cultural world.
\end{abstract}

Keywords: myth; mythonym; onomastics; general cultural lexicon; weapons; protective equipment.

\section{Introduction}

Proper names are important source of information and compile significant part of English and German languages.

The most important features of lexical meaning of proper names are their formation in the course of historical development of language, their objectivity and comprehensibility [1:77].

The relevance of the study is due to ancient mythonyms denoting weapons and protective equipment are insufficiently studied both in native and in foreign linguistics.

The magical function of language in archaic cultures is due to mythological beliefs of the people and inspiration of the whole world. In the opinion of E. Cassirer, the structure of the mythological language of the world is largely determined by the same spiritual concepts: «The myth revives and enriches itself due to the language, and the language revives and enriches itself due to the myth» [2:41]. 
The lack of complete research of the lexical and etymological features of ancient mythonyms in English and German languages leads to some difficulties in translation of literature and through intercultural communication.

The novelty of this study is defined by the fact that the comprehensive study of ancient mythonyms denoting weapons and protective equipment in English and German languages is carried out for the first time.

Lexical and etymological analysis of ancient mythonyms in English and German languages is carried out and thematic classification is given for the first time.

The main purpose of this work is to identify the cultural characteristics of ancient mythonyms in English and German languages through etymological analysis.

The practical significance of the study is that the results can be used in the preparation of the English-German onomastic dictionaries, in the preparation of courses, special courses and textbooks on lexicology.

Seventy-two English and German lexical units (ancient mythonyms) served as the material for the research and were selected by continuous sampling from English and German lexicographical sources.

\section{Methodology}

While analyzing ancient mythonyms denoting weapons and protective equipment in English and German languages we resorted to a number of methodological techniques, namely:

- continuous sampling;

- lexical analysis;

- etymological and semantic analysis.

The works of foreign and native authors serve the theoretical framework of the study:

- on onomastics: A.V. Superanskaya [5], A. Gardiner [6];

- on mythology: A.F. Losev [3]; E.M. Meletinsky [4].

\section{Classification}

The names of ancient weapons and protective equipment with component-mythonym in English and German languages, such as swords, cudgels, tridents, spears, bows, arrows and shields are considered in the paper. They reflect historical and cultural information, have peculiar cognitive classification.

\section{Weapons}

\section{Tridents}

eng. trident of Neptune - germ. Neptun Dreizack (caused earthquakes and gave birth to horses by its hitting the solid earth. It was done by Cyclopes); 
eng. trident of Hades - germ. Hades Dreizack (Hades was the god of the underground kingdom and the realm of the dead);

eng. trident of Satan - germ. Satan Dreizack (trident in the hands of Satan symbolized the principle «to divide and rule»).

\section{Spears}

eng. spear of Athena - germ. Athene Speer (by its hitting the ground the first olive tree appeared. Athena was depicted wearing a helm, with a shield and a spear);

eng. spear of Peleus - germ. Peleus Speer (was made of Pelion ash, hard as iron. It was a gift from the centaur Chiron for the wedding of the hero with Thetis, then it belonged to their son Achilles);

eng. marvelous spear of Procris - germ. zauberhaft Prokris Speer (Procris was the character in Greek mythology. She received a marvelous spear from goddess Artemis as a gift. It hit the target and returned itself to the one who had thrown it).

\section{Bows}

eng. bow of Apollo - germ. Apollon Bogen (its arrows brought such disease as plague);

eng. bow of Artemis - germ. Artemis Bogen (it was made by Cyclops in the forge of Hephaestus. Artemis discharged two first arrows into the trees, the third one into the animal, the fourth one into the impious town which did not know fairness of people);

eng. bow of Heracles - germ. Herakles Bogen (Heracles performed some of his exploits with the help of the bow, e.g. freed the chained Prometheus);

eng. bow of Odysseus - germ. Odysseus Bogen (Odysseus was the only one who could shoot the bow's bolt);

eng. bow of Eros - germ. Eros Bogen (its arrows brought love).

\section{Arrows}

eng. arrow of Apollo - germ. Apollon Pfeil (Apollo killed the Cyclops with the help of his arrow);

eng. arrow of Heracles - germ. Herakles Pfeil (Heracles killed the eagle tearing the liver of Prometheus with the help of his arrow);

eng. arrow of Paris - germ. Paris Pfeil (the arrow hit the heel of Achilles, the Achaean hero. The flight of the arrow was directed by Apollo himself). 


\section{Swords, cudgels}

eng. sword of Perseus - germ. Schwert des Perseus (Perseus was the son of Zeus and the Argive princess Danae. Perseus killed the Gorgon Medusa with the help of his sword. He freed Andromeda, who became his wife);

eng. cudgel of Hercules - germ. Herkules Bengel (it was a gift from Daedalus. Hercules made the cudgel from the torn roots of solid as iron ash in the Nemean grove).

\section{Protective equipment}

\section{Shields}

eng. shield of Athena and Zeus - germ. Athene und Zeus Schild (the image of Medusa Gorgon was depicted on the shield. In Greek mythology it was named Aegis. The shield was made of skin of Amalthea, the goat which reared Zeus);

eng. shield of Mars - germ. Mars Schild (the shield which in the reign of Numa Pompilius fell from the sky. It became the guarantee of security and prosperity of Roman state);

eng. shield of Achilles - germ. Achilleus Schild (it was forged in one night by Hephaestus. Hephaestus depicted the earth, the sky, the stars, as well as numerous episodes of urban and rural life on the shield);

eng. shield of Heracles - germ. Herakles Schild (it was brilliant, colourful, diverse, agile, nimble and sparkling. Two worlds are depicted on the shield: the underground kingdom and the kingdom of all living things);

eng. shield of Ajax - germ. Ajax Schild (it was made of seven layers of bovine leather. It was an oval, impenetrable shield in the form of a huge hyacinth with a lion depicted on it);

eng. mirror shield of Perseus - germ. Perseus Spiegelschild (it was polished up to the high finish. Perseus could see the Gorgon in the reflection of his shield and not to turn into a stone).

\section{Conclusion}

The names of weapons and protective equipment in English and German languages composed of proper names belonging to ancient myths summarize the events, the facts associated with these names. Words and word elements of bygone epochs preserved in the names of mythical creatures.

The analysis of the names of ancient weapons and protective equipment with components-mythonyms in English and German languages revealed that in most cases they are of the same lexical meaning and relate to general cultural 
lexicon, as they are found in two languages and have the same source language. But they have phonetic and graphic differences connected with the peculiarities of pronunciation and spelling in English and German.

The names of weapons and protective equipment entered the vocabulary of English and German languages and were named after mythical characters or ancient heroes.

Mythonyms for denoting ancient weapons and protective equipment have national cultural identity and concentrate facts forgotten by a man, i.e. they are the keepers of information and are the heritage of cultural world.

\section{References}

1. Kuchesheva, I.L.: Nekototye osobennosti perenosa imen sobstvennykh na predmety material'noj dejstvitel'nosti: lingvokul'turologicheskij podkhod [Some peculiarities of transfer of proper names to the objects of material reality: linguistic cultural approach] // Inostrannye yazyki v shkole. 3. pp. 77-80 (2010). (In Russian)

2. Cassirer, E.: Sila metafory // Teoriya metafory [The power of metaphor // The theory of metaphor]. Moscow, Progress. (1990). (In Russian)

3. Losev, A.F.: Znak. Simvol. Mif [Sign, Symbol, Myth] M.: Ed. MSU. (1982) (In Russian)

4. Meletinsky, Y.M. Mif i istoricheskaia poetika folklora. [Myth and historic poetry of folklore. Folklore. Poetic system] M.: Nauka. pp. 23-41 (1977). (In Russian)

5. Superanskaja, A.V.: Obshchaja teorija imeni sobstvennogo [The General theory of a proper name] M.: Nauka. (1973). (In Russian)

6. Gardiner, A. H.: The theory of proper names: A controversial essay. London/New York: Oxford University Press (1957)

7. Prokop'eva, N.N., Plisov, E.V.: Bol'shoj nemetsko-russkij i russko-nemetskij slovar'. [Big German-Russian and Russian-German dictionary] Moscow: Tsentrpoligraf. (2001). (In Russian)

8. Muzhzhevlev, E.A., Rydnik, V.I.: Anglo-russkij tematicheskij slovar' [English-Russian thematic dictionary] Moscow: Russkij Yazyk. (1994). (In Russian)

9. Muller, V.K.: Anglo-russkij i russko-anglijskij slovar' [English-Russian and RussianEnglish dictionary] Moscow: Eksmo. (2011). (In Russian)

10. Novyj bol'shoj anglo-russkij slovar' [New big English-Russian Dictionary] / Ed. E.M. Mednikova and Y.D. Apresyan. M .: Russian Language. (1993). (In Russian)

11. Bildworterbuch Russisch // Compact Verlag. (2013)

12. Cambridge Advanced Learner's Dictionary Hardback (4th edition) // Colin McIntosh. (2013)

13. Elektronnyj slovar' ABBYY LINGVO 12 [Electronic Dictionary ABBYY LINGVO 12 multilingual]. (2006)

14. Langescheidt Universal-Worterbuch Russisch // Langenscheidt. (2014)

15. Longman Collocations Dictionary and Thesaurus // Pearson Educated Limited. (2015)

Information about the author:

Kuchesheva I.L. - Ph.D., Associate Professor, Department «Public Relations and Foreign Languages», Siberian State University of Physical Education and Sport (Omsk, Russia). E-mail: kuchesheva@rambler.ru 